\title{
DNA Repair Protein XRCC1
}

National Cancer Institute

\section{Source}

National Cancer Institute. DNA Repair Protein XRCC1. NCI Thesaurus. Code C21565.

DNA repair protein XRCC1 (633 aa, $\sim 69 \mathrm{kDa}$ ) is encoded by the human XRCC1 gene. This protein is involved in repair of both DNA strand breakage and improper sister chromatid exchange. 